\title{
RESPON SISWA DAN GURU TERHADAP MODUL ETHNO-EDUTAINMENT DI SEKOLAH ISLAM TERPADU
}

\author{
Sekar Dwi Ardianti \\ Universitas Muria Kudus, Kudus, Indonesia \\ sekar.dwi.ardianti@umk.ac.id \\ Savitri Wanabuliandari \\ Universitas Muria Kudus, Kudus, Indonesia \\ savitri.wanabuliandari@umk.ac.id \\ Savitri Wanabuliandario \\ Universitas Negeri Semarang, Semarang, Indonesia \\ sigit_biounnes@mail.unnes.ac.id \\ Siti Alimah \\ Universitas Negeri Semarang, Semarang, Indonesia \\ siti_alimah@mail.unnes.ac.id
}

\begin{abstract}
STUDENTS AND TEACHERS RESPONSE ON ETHNOEDUTAINMENT MODULES IN INTEGRATED ISLAMIC SCHOOLS The results of a preliminary study conducted at SD IT Umar Bin Khattab showed that the teaching materials used in learning were books from the government and several books from other publishers which the learning materials have not been able to describe the real conditions in the surrounding, especially Kudus. This study aims to analyze the practicality of ethno-edutainment modules in Islamic-based elementary schools in Kudus. The ethno-edutainment module was developed with a modified Borg and Gall model included the preliminary study phase, product development and validation stages, and product testing stages in limited and wide scale. Practical tests were carried out at the wide-scale test phase with research
\end{abstract}


subjects of grade IV students at SD IT Umar Bin Khattab. The practicality of ethno-edutainment modules is assessed by using student response questionnaires and interviews with teachers. The students responses to ethno-edutainment modules show that $87.5 \%$ students respond positively. The teachers also give positive response to the ethno-edutainment module.

Keywords: student response; teacher, integrated Islamic school; module; ethno-edutainment.

\begin{abstract}
Abstrak
Hasil studi pendahuluan di SD IT Umar Bin Khattab diketahui bahwa bahan ajar yang digunakan dalam pembelajaran berupa buku dari pemerintah dan buku dari penerbit lain yang materinya belum mampu menggambarkan kondisi nyata di lingkungan sekitar, khususnya daerah Kudus. Penelitian ini bertujuan untuk menganalisis kepraktisan modul ethno-edutainment pada siswa sekolah dasar berbasis islam di Kudus. Modul ethno-edutainment dikembangkan dengan model Borg and Gall yang dimodifikasi meliputi tahap studi pendahuluan, tahap pengembangan dan validasi produk, serta tahap uji coba produk skala terbatas dan luas. Uji kepraktisan dilakukan pada tahap uji skala luas dengan subjek penelitian siswa kelas IV di SD IT Umar Bin Khattab. Kepraktisan modul ethno-edutainment dinilai dengan menggunakan angket respon siswa dan wawancara terhadap guru. Hasil respon siswa terhadap modul ethno-edutainment menunjukkan bahwa $87,5 \%$ siswa memberikan respon positif. Guru juga memberikan respon positif terhadap modul ethno-edutainment.
\end{abstract}

Kata Kunci: respon siswa; guru, sekolah islam terpadu; modul; ethnoedutainment.

\title{
A. Pendahuluan
}

Pendidikan merubah kehidupan manusia menjadi lebih baik. Perubahan ini dapat terwujud dengan bantuan guru sebagai tenaga pendidik. Agar perubahan yang terjadi sesuai dengan perkembangan zaman, seorang guru harus selalu memperhatikan perkembangan Ilmu Pengetahuan dan Teknologi (IPTEK). Dengan memperhatikan perkembangan IPTEK dapat membantu guru untuk meningkatkan keterampilan dalam mengelola proses pembelajaran di dalam kelas. Kualitas proses pembelajaran di dalam kelas juga ditentukan oleh keterampilan guru dalam mengelola proses pembelajaran. 
Salah satu cara meningkatkan keterampilan guru dalam mengelola proses pembelajaran adalah dengan memperkaya sumber dan media pembelajaran. (Daryanto, 2013) menjelaskan bahwa memperkaya sumber dan media pembelajaran dapat dilakukan dengan mengolah informasi di lingkungan siswa. Mengolah informasi di lingkungan siswa dapat dilakukan dengan menghubungkan materi dengan kebudayaan di sekitar siswa. (Wanabuliandari, S., Ardianti, S., Saptono, S., Alimah, S., \& Kurniasih., 2018) menyebutkan bahwa budaya lokal mempermudah siswa dalam memahami materi karena sangat dekat dengan lingkungan sekitar siswa. Kondisi lingkungan sekitar apabila digunakan sebagai sumber belajar dapat menjadikan pembelajaran lebih bermakna. (Ardianti, S.D., Wanabuliandari, S., \& Rahardjo, 2017) menyatakan bahwa penggunaan lingkungan sekitar sebagai sumber belajar siswa dapat menunjang kegiatan pembelajaran secara optimal sehingga siswa lebih memahami materi dikarenakan pembelajaran bersifat nyata. Selain itu, menurut (Wanabuliandari, 2016) melalui budaya lokal dapat membantu guru untuk menanamkan karakter. Karakter ini dapat muncul apabila didukung dengan sumber dan media pembelajaran yang sesuai.

Salah satu cara menggunakan sumber dan media pembelajaran yang dapat menanamkan karakter adalah melalui bahan ajar. Bahan ajar yang dikembangkan dapat bervariasi sesuai dengan kebutuhan siswa. Bahan ajar yang digunakan dalam pembelajaran dapat mempengaruhi kualitas pembelajaran (Ardianti, 2015). Pemilihan bahan ajar juga perlu diperhatikan khususnya oleh seorang guru. (Rosyidah, A.N., Sudarmin, S.S., \& Siadi, 2013) menyatakan bahwa bahan ajar dikatakan baik apabila memiliki kriteria tertentu antara lain relevansi dengan kurikulum, kesesuaian dengan metode, dan materi pembelajaran. Hal tersebut dikarenakan bahan ajar sebagai salah satu komponen pembelajaran yang berkaitan langsung dengan siswa.

Salah satu bahan ajar yang dapat digunakan oleh siswa dapat berupa modul. Modul dapat membantu siswa untuk belajar secara mandiri sehingga akan memudahkan siswa untuk belajar dimanapun dan kapanpun. (Daryanto, 2013) mendefinisikan bahwa modul merupakan bahan ajar yang disusun secara sistematis dan utuh yang akan membantu siswa untuk mencapai tujuan pembelajaran baiksecara mandiri ataupun kelompok. Penggunaan modul dalam pembelajaran 
dapat membantu siswa untuk memperoleh pemahaman terhadap konsep ataupun materi pembelajaran (Ardianti, S.D, \& Ristiyani, 2017). Modul yang digunakan oleh siswa dapat dikembangkan sesuai dengan kebutuhan dan karakteristik siswa. Dengan menggunakan modul berkonten ethno atau berkaitan dengan budaya akan membantu siswa dalam memahami materi maupun membantu guru menanamkan karakter terutama karakter cinta tanah air. Kebudayaan sekitar bersifat nyata sehingga akan mempermudah siswa dalam memahami materi berdasarkan contoh-contoh dari budaya yang ada di lingkungan sekitar. (Ardianti, S.D., Wanabuliandari, S., \& Rahardjo, 2017) menyatakan bahwa penggunaan sumber belajar dari lingkungan sekitar dapat menunjang kegiatan pembelajaran secara optimal sehingga siswa lebih memahami materi dikarenakan pembelajaran bersifat nyata.

Dalam penanaman karakter cinta tanah air ini sekolah berbasis Islam memiliki beberapa kendala. (Agustinova, 2014) menyebutkan salah satu hambatan dalam menanamkan karakter adalah tidak adanya sarana dan prasarana yang mendukung. Selain itu, model sekolah islam terpadu biasanya menggunakan model full day school dimana model ini menuntut siswa untuk seharian berada dilingkungan sekolah. (Hawi, 2015) menyatakan bahwa sekolah berbasis islam terpadu menerapkan sistem pembelajaran full day school dimana siswa berada di sekolah kurang lebih selama 8 (delapan) jam sehari yang memerlukan ruang gerak yang cukup untuk semua aktivitas siswa selama di sekolah.

Salah satu sekolah islam terpadu adalah SD IT Umar Bin Khattab. SD IT Umar bin Khattab berada di Kabupaten Kudus. Berdasarkan studi pendahuluan SD IT Umar bin Khattab merupakan salah satu sekolah islam terpadu yang memiliki kesulitan dalam menanamkan karakter cinta tanah air dalam kegiatan pembelajaran. Hal ini dikarenakan SD IT Umar Bin Khattab merupakan sekolah berlatar belakang islam yang lebih mengutamakan nilai-nilai Islam dibandingkan sekolah regular lainnya. (Agustina, S., Suntoro, I., \& Nurmalisa, 2013) dalam penelitiannya menyatakan bahwa sekolah berbasis islam terpadu memiliki peran yang sangat kuat dan signifikans dalam pembentukan karakter religius siswa. Hal tersebut juga didukung pendapat (Suyatno, 2013) bahwa pada 
sekolah berbasis islam terpadu pembelajaran dan kegiatan di sekolah lebih ditekankan pada penanaman nilai-nilai moral keagamaan dan pendidikan modern. Walaupun pada sekolah berbasis islam terpadu lebih mengutamakan penanaman nilai karakter keislaman, diharapkan nilai karakter lainnya khususnya karakter cinta tanah air juga dapat terbentuk dengan baik pada diri siswa. Beberapa langkah yang dilakukan sekolah dalam menanamkan karakter cinta tanah air adalah dengan memfasilitasi ekstra angklung setiap hari sabtu, mengadakan upacara bendera setiap hari senin, dan setiap tahun mengadakan kunjungan ke museum jenang. Akan tetapi kegiatan tersebut masih kurang maksimal dalam menanamkan karakter cinta tanah air.

Hasil studi pendahuluan yang telah dilakukan di SD IT Umar Bin Khattab diketahui bahwa bahan ajar yang digunakan dalam pembelajaran selama ini berupa buku dari pemerintah dan beberapa buku dari penerbit lain yang beredar di pasaran. (Efendi, 2009) memaparkan salah satu kelemahan buku dari pemerintah adalah kurang melibatkan siswa dalam menemukan pengalaman, penyajian tidak disusun agar siswa dapat mencari tahu sendiri, pengolahan bahan materi kurang disesuaika dengan perkembangan psikologi siswa sehingga kurang menarik, keterbacaan masih rendah karena menggunakan kata yang sulit dan kalimat yang terlalu panjang, tingkat kesulitan kurang disesuaikan dengan jenjang pendidikan, istilah kurang diuraikan dengan baik dan siswa diminta langsung mengerjakan, Pilihan wacana terlalu berat dan kurang variatif, banyak gambar yang tidak sesuai dengan isi wacana, tidak menyediakan soal evaluasi, serta gambarnya sedikit. Materi pembelajaran yang disajikan dalam buku juga belum mampu menggambarkan kondisi nyata di lingkungan sekitar. Oleh karena itu, perlu adanya sumber dan media pembelajaran yang berkaitan dengan lingkungan sekitar agar dapat mendukung kegiatan pembelajaran yang lebih baik.

Kondisi lingkungan sekitar apabila digunakan sebagai sumber dan media belajar dapat menjadikan pembelajaran lebih bermakna. (Ardianti, S.D., Wanabuliandari, S., \& Rahardjo, 2017) menyatakan bahwa penggunaan lingkungan sekitar sebagai sumber belajar siswa dapat menunjang kegiatan pembelajaran secara optimal sehingga siswa lebih memahami materi dikarenakan pembelajaran bersifat nyata. Sumber dan media pembelajaran yang berasal dari 
lingkungan sekitar salah satunya dapat berupa keunggulan lokal dan kebudayaan daerah. Hal ini dapat dilakukan dengan bantuan modul berkonten ethno.

Melalui modul berkonten ethno guru akan lebih mudah menanamkan karakter cinta tanah air melalui budaya lokal di sekitar siswa. Karena budaya lokal merupakan dasar dari budaya bangsa. (Brata, 2016) menyatakan bahwa budaya lokal sebagai unsur kebudayaan yang harus digali, dikaji, dan direvitalisasi karena unsur budaya lokal memiliki esensi yang penting untuk penguatan fondasi atau dasar jati diri suatu bangsa dalam menghadapi tantangan globalisasi. Dengan pengenalan budaya lokal sejak dini akan membantu siswa mencintai kebudayaan sendiri sehingga tidak akan mudah terpengaruh oleh budaya asing yang masuk ke Indonesia. (Brata, 2016) juga menyatakan bahwa budaya lokal dapat dijadikan sebagai perekat identitas suatu bangsa dalam menghadapi tantangan di era globalisasi. Hal senada juga diungkapkan oleh (Wanabuliandari, S., \& Ardianti, 2018) bahwa melalui lingkungan sekitar dapat membantu guru dalam mengembangkan karakter siswa. Dengan demikian, generasi muda penerus bangsa tidak akan mudah terpengaruh isu yang dapat memecah belah persatuan dan kesatuan bangsa.

Salah satu contoh konten ethno yang dikembangkan peneliti adalah tentang keunggulan maupun kearifan lokal kota Kudus. Kudus sebagai salah satu kabupaten di Provinsi Jawa Tengah yang terkenal dengan Sunan Kudus dan keunggulan lokal berupa menara Kudus dan Jenang Kudus. Penyebaran agama islam oleh Sunan Kudus dapat digunakan sebagai salah satu referensi sumber dan media belajar khususnya di SD Islam Terpadu di Kudus. Contoh konten ethno yang berkaitan dengan kota Kudus adalah cerita tentang Sunan Kudus. Selain dapat dikaitkan dengan budaya sekitar dapat juga dikaitkan dengan nilai-nilai Islami. Cerita budaya lokal khususnya mengenai Sunan Kudus dalam menyebarkan agama Islam dan akhirnya membangun sebuah masjid Al-Quds sebagai salah satu cerita asal mula daerah Kudus dikaitkan dengan materi pembelajaran untuk siswa sekolah dasar. Penggunaan cerita daerah tersebut akan mempermudah siswa dalam memahami materi juga menanamkan karakter cinta tanah air. 
Selain menggunakan konten ethno, pengembangan modul perlu memasukkan unsur edutainment agar kegiatan pembelajaran lebih menarik dan menyenangkan. (Pratiwi, I.A., Ardianti, S.D., \& Kanzunnudin, 2018) mengemukakan bahwa edutainment sebagai desain pembelajaran dimana muatan pembelajaran dikombinasi dengan hiburan yang bersifat menyenangkan. Senada dengan pendapat (Ardianti, S.D., Pratiwi, I.A., \& Kanzunnudin, 2017) yang menyatakan bahwa edutainment sebagai pembelajaran yang dikemas secara menarik dan menyenangkan melalui kegiatan, media, ataupun bahan ajar yang digunakan tanpa melupakan tujuan pembelajaran. Pendekatan edutainment perlu diterapkan pada siswa sekolah dasar mengingat sifat dasar alamiah seorang anak yang masih duduk di bangku sekolah dasar adalah bermain. Hal ini perlu dilakukan mengingat SD IT Umar Bin Khattab merupakan sekolah dengan sistem full day school. Sistem full day school menuntut siswa untuk berada di lingkungan sekolah selama seharian penuh. Melalui penetapan sistem full day school diharapkan siswa leh konsentrasi dalam belajar. Waktu belajar di SD IT Umar Bin Khattab adalah dari pukul 07.00 WIB - pukul 15.30 WIB dengan muatan kurikulum yang berkaitan dengan pendidikan umum, agama serta keterampilan. Dengan demikian jelas bahwa siswa membutuhkan waktu belajar yang lebih lama daripada di sekolah biasa.

Salah satu kelemahan dari sistem full day school menurut (Agustinova, 2014) adalah waktu untuk bermain dengan lingkungan sekitar menjadi berkurang. Hal ini lah yang menjadikan siswa cepat jenuh dengan pembelajaran jika tidak didukung dengan sumber dan media pembelajaran yang menarik. Hal ini dapat diatasi dengan memasukkan edutainment ke dalam modul berkonten ethno. Sebagaimana karakteristik pembelajaran untuk siswa sekolah dasar diharapkan dapat dikemas dalam bentuk pembelajaran yang menyenangkan (edutainment). Memasukkan edutainment dilakukan dengan menambahkan komik, gambar yang menarik, serta kegiatan bermain sambil belajar. (Wanabuliandari, S., Ardianti, S., D., \& Rahardjo, 2016) menyebutkan bahwa edutainment dapat digunakan sebagai salah satu langkah membuat pembelajaran lebih menarik dan siswa dapat bermain sambil belajar. 
Dengan demikian, melalui pengembangan modul ethnoedutainment dapat membantu guru dalam menanamkan karakter dan meningkatkan keterampilan guru dalam pengelolaan pembelajaran serta dapat membantu siswa dalam memahami materi sehingga pembelajaran lebih bermakna. Dalam pengembangan modul ethnoedutainment perlu diuji kepraktisannya untuk mengetahui seberapa baik dan menarik modul untuk digunakan sebagai bahan ajar menurut siswa dan guru. Kepraktisan modul ethno-edutainment dapat diperoleh melalui respon siswa dan guru terhadap modul ethnoedutainment. (Alfiriani, A., Hutabri, 2017) menyatakan bahwa modul perlu diuji kepraktisannya untuk mengetahui kriteria kualitas modul sehingga dapat digunakan sebagai sumber belajar.

Respon siswa terhadap modul ethno-edutainment adalah tanggapan siswa terhadap penggunaan modul ethno-edutainmen dalam pembelajaran di kelas. Sedangkan respon guru terhadap modul ethno-edutainment berupa tanggapan dalam bentuk pernyataan yang berkaitan dengan isi materi dan penggunaan modul ethnoedutainment. Seseorang dapat merespon suatu objek jika obyek tersebut menarik perhatian. Selain itu, munculnya respon dikaitkan oleh faktor yang mempengaruhi seperti pengalaman yang diperoleh maupun proses belajar yang sudah dilakukan. Respon dapat berbentuk pendapat yang dikemukakan secara logis. Respon dapat berbentuk sikap positif maupun negatif terhadap obyek yang sudah diamati. Hal ini berarti bahwa respon merupakan reaksi maupun kesan yang didapatkan pengamat setelah mengamati kegiatan yang berkaitan dengan indra dan menilai suatu objek.

Berdasarkan uraian diatas maka tujuan dari penelitian ini adalah untuk menganalisis seberapa besar respon siswa terhadap penggunaan modul ethno-edutainment di SD IT Umar Bin Khattab serta untuk mendeskripsikan respon guru terhadap isi materi dan penggunaan modul ethno-edutainment di SD IT Umar Bin Khattab.

Penelitian ini merupakan jenis penelitian R\&D (Research and Development) dengan menggunakan tahapan penelitian pengembangan dari Borg dan Gall yang telah dimodifikasi. Desain dari Borg dan Gall meliputi beberapa tahapan. Tahap penelitian ini meliputi tahap studi pendahuluan, tahap pengembangan dan validasi produk, serta tahap uji coba produk. 
Tahap studi pendahuluan dilakukan untuk mengetahui data awal yang berkaitan dengan kebutuhan pengembangan modul ethnoedutainment. Hasil dari studi pendahuluan digunakan sebagai dasar dalam pengembangan modul ethno-edutainment. Tahap selanjutnya adalah validasi modul ethno-edutainmentpada ahli. Modul ethnoedutainment yang telah dikembangkan selanjutnya divalidasi oleh tiga ahli yaitu ahli materi, ahli bahasa, dan ahli pembelajaran sehingga menghasilkan draft modul ethno-edutainment yang siap untuk diujicobakan secara terbatas dan luas. Modul ethno-edutainment yang telah divalidasi selanjutnya diujicobakan secara terbatas dan luas.

Uji coba terbatas ini dilakukan untuk mengetahui pendapat siswa sebagai pengguna mengenai modul ethno-edutainment. Uji coba terbatas dilakukan dengan mengambil 10 siswa di kelas IV. Siswa diberikan angket untuk menilai dan memberikan saran pada modul ethno-edutainment. Setelah melakukan uji coba terbatas langkah selajutnya adalah merevisi produk berdasarkan penilaian dan saran dari hasil uji coba skala terbatas. Kemudian dilanjutkan dengan melakukan uji coba produk skala luas.

Pada tahap uji coba produk skala luas, peneliti melaksanakan ujicoba produk dengan sasaran yang lebih luas. Uji coba produk skala luas dilakukan pada siswa kelas IV di SD IT Umar Bin Khattab. Pada tahap ini, peneliti melaksanakan uji kepraktisan dalam penggunaan modul ethno-edutainment. Uji kepraktisan dilakukan dengan tujuan untuk memperoleh saran dan masukan dari siswa terhadap penggunaan modul ethno-edutainment. Modul ethno-edutainment dikatakan praktis jika memenuhi kriteria yaitu (1) banyaknya siswa yang memberikan respon positiflebih dari atau sama dengan $80 \%$, dan (2) respon guru terhadap modul ethno-edutainment minimal baik.

Teknik pengumpulan data yang digunakan dalam penelitian ini adalah teknik non tes berupa angket respon siswa terhadap modul ethno-edutainment. Instrumen penelitian ini menggunakan angket respon siswa dan lembar wawancara guru. Salah satu contoh item yang ada di dalam angket respon siswa adalah "Materi pelajaran yang saya terima menjadi lebih nyata". Setelah melaksanakan pengumpulan data kemudian data tersebut dibagi menjadi dua kelompok, yaitu data kuantitatif dan data kualitatif. Data kuantitatif berupa angka-angka yang berasal dari perhitungan angket respon siswa. Sedangkan data 
kualitatif berupa kata-kata atau kalimat dari hasil deskripsi wawancara dengan guru.

Setelah melaksanakan pengumpulan data, langkah selanjutnya adalah melaksanakan analisis data. Data dianalisis secara kuantitatif dan kualitatif. Teknik analisis data kuantitatif dilakukan dengan menentukan rata-rata skor angket respon siswa. Sedangkan analisis data kualitatif dilakukan secara diskriptif berdasarkan hasil wawancara terhadap guru. Skor respon siswa dihitung dengan rumus sebagai berikut.

$$
\text { skor respon siswa }=\frac{\text { jumlah skor yang diperoleh }}{\text { jumlah skor maksimal }} \times 100
$$

Setelah diperoleh skor respon masing-masing siswa, selnjutnya menentukan kriteria respon siswa. Untuk menentukan kriteria dari skor respon siswa menggunakan Tabel 1. berikut ini.

Tabel 1. Kriteria Respon Siswa

\begin{tabular}{cc}
\hline Skor Respon Siswa & Kriteria Respon \\
\hline $76 \leq$ Persentase skor respon siswa $\leq 100$ & Positif \\
$56 \leq$ Persentase skor respon siswa $\leq 75$ & Sedang \\
$0 \leq$ Persentase skor respon siswa $\leq 55$ & Negatif \\
\hline
\end{tabular}

Setelah siswa dikelompokan berdasarkan kriteria respon siswa pada Tabel 1, selanjutnya dihitung jumlah siswa yang memberikan respon positif. Mencari persentase siswa yang memberikan respon positif menggunakan rumus berikut ini.

persentase siswa respon positif $=\frac{\text { jumlah siswa yang memperoleh respon positif }}{\text { jumlah seluruh siswa }} \times 100 \%$

Menurut (Hobri, 2009) respon siswa dapat digunakan untuk menentukan capaian tujuan pembelajaran, jika banyaknya siswa yang memberikan respon positif lebih besar atau sama dengan $80 \%$ dari subjek yang diteliti.

\section{B. Pembahasan}

Penelitian dilaksanakan di SD Umar Bin Khattab pada siswa kelas IV. Penelitian ini merupakan jenis penelitian pengembangan dari Borg dan Gall yang telah dimodifikasi oleh peneliti. Tahapan 
Respon Siswa dan Guru Terhadap Modul Ethno-Edutainment di sekolah Islam Terpadu

dalam penelitian ini meliputi tahap studi pendahuluan, tahap pengembangan dan validasi produk, serta tahap uji coba produk.

Pada tahap studi pendahuluan yang dilakukan adalah mencari literatur dan studi lapangan dengan tujuan membekali peneliti tentang informasi sementara terkait pengembangan modul ethno-edutainment, menjelaskan teori modul ethno-edutainment dan perbandingan dengan penelitian yang relevan dalam pengembangan modul ethnoedutainment. Dari kegiatan analisis tersebut, peneliti menemukan bahwa karakter cinta tanah air pada generasi muda saat ini masih rendah. Berdasarkan hasil observasi di SD IT Umar Bin Khattab didapatkan hasil bahwa karakter cinta tanah air siswa masih rendah, guru masih kesulitan dalam menanamkan karakter cinta tanah air dalam pembelajaran di kelas, dan guru belum mengembangkan bahan ajar yang dapat mendukung karakter cinta tanah air.

Setelah melaksanakan observasi, peneliti melaksanakan analisis kebutuhan dengan hasil ada kebutuhan siswa terhadap modul yang menyenangkan, ada kebutuhan siswa terhadap pengembangan pembelajaran berbasis ethno, serta ada kebutuhan siswa terhadap penanaman karakter cinta tanah air. Sedangkan hasil wawancara dengan guru menunjukkan bahwa ketersediaan bahan ajar yang yang menyenangkan dengan memasukkan unsur-unsur budaya untuk membantu meningkatkan karakter cinta tanah air masih sangat terbatas. Bahan ajar yang tersedia hanya menekankan konsep sehingga belum dapat menghubungkan budaya di lingkungan sekitar dengan materi pelajaran.

Tahapan selanjutnya adalah tahap pengembangan dan validasi produk. Peneliti melaksanakan penyusunan modul ethno-edutainment dengan memperhatikan kurikulum yang ada. Setelah tersusun modul ethno-edutainment langkah selanjutnya adalah melakukan validasi validasi produk oleh ahli. Validasi produk oleh ahli terdiri dari 3 validator yaitu ahli materi, ahli bahasa, dan ahli pembelajaran. Ketiga ahli tersebut memberikan penilaian dan saran terhadap produk yang sudah dibuat. Dari hasil penilaian dan saran didapatkan hasil bahwa modul ethno-edutainment pada kategori sangat layak.

Setelah melaksanakan validasi produk oleh ahli, langkah selanjutnya adalah uji coba produk. Uji coba produk meliputi uji coba terbatas dan uji coba skala luas. Uji coba terbatas ini dilakukan 
untuk mengetahui pendapat siswa sebagai pengguna mengenai modul ethno-edutainment. Berdasarkan masukan dari uji skala terbatas kemudian dilakukan revisi. Kemudian dilanjutkan dengan Uji coba skala terbatas.

Pada tahap uji coba skala luas, peneliti melaksanakan uji kepraktisan dalam penggunaan modul ethno-edutainment. Uji kepraktisan dilakukan dengan tujuan untuk memperoleh saran dan masukan dari siswa dan guru terhadap penggunaan modul ethnoedutainment. Kepraktisan modul ethno-edutainment ditentukan berdasarkan angket respon siswa dan wawancara terhadap guru. Hasil dari uji kepraktisan adalah sebagai berikut.

\section{Hasil Analisis Respon Siswa Terhadap Modul Ethno- Edutainment}

Respon siswa merupakan suatu tanggapan atau perasaan siswa setelah mengikuti kegiatan pembelajaran. Data respon siswa yang diperoleh dengan menggunakan angket respon siswa dan dianalisis secara kuantitatif. Pertama menentukan skor respon masing-masingmasing siswa, kemudian ditentukan termasuk kategori yang mana. Setelah itu, dihitung persentase siswa yang memperoleh kriteria positif. Indikator keberhasilan apabila hasil persentase angket respon siswa yang mendapatkan respon positif lebih dari atau sama dengan $80 \%$.

Secara umum siswa memberikan respon positif terhadap penggunaan modul ethno-edutainment dalam pembelajaran. Respon siswa yang diukur dalam penelitian ini terdiri atas 3 aspek pengamatan yaitu tanggapan siswa terhadap kemenarikan modul, bahasa modul, dan materi modul setalah pembelajaran dimulai. Pada Tabel 2 menunjukkan hasil rekapitulasi skor respon siswa berdasarkan aspek yang diamati terhadap modul ethno-edutainment dalam pembelajaran.

Tabel 2. Rekapitulasi skor respon siswa berdasarkan aspek yang diamati

\begin{tabular}{ccc}
\hline Aspek Yang Diamati & Jumlah Skor & Persentase \\
\hline Kemenarikan & 472 & $92,2 \%$ \\
Bahasa & 225 & $87,9 \%$ \\
Materi & 447 & $87,3 \%$ \\
\hline
\end{tabular}


Dari Tabel 2 menunjukkan bahwa pada aspek kemenarikan modul saat pembelajaran mendapatkan jumlah skor 472 atau aspek kemenarikan dipilih sebanya 92,2\% siswa setuju bahwa modul ethnoedutainment menarik. Aspek bahasa mendapatkan jumlah skor 225 yang berarti $87,9 \%$ siswa setuju bahwa modul ethno-edutainment menggunakan bahasa yang baik, mudah dimengerti dan sistematis. Sedangkan pada aspek materi mendapatkan jumlah skor 447 yang artinya $87,3 \%$ siswa setuju bahwa materi yang di uraikan membuat siswa lebih aktif dan lebih mudah memahami materi.

Selanjutnya rekapitulasi hasil analisis angket respon tanggapan siswa pada setiap pernyataan terhadap modul ethno-edutainment disajikan pada Tabel 3 berikut ini.

Tabel 3. Rekapitulasi angket tanggapan siswa

\begin{tabular}{|c|c|c|c|}
\hline \multirow{2}{*}{ No } & \multirow{2}{*}{ Pernyataan } & \multicolumn{2}{|c|}{ Jawaban (\%) } \\
\hline & & Ya & Tidak \\
\hline 1 & $\begin{array}{l}\text { Modul tidak menarik digunakan dalam } \\
\text { pembelajaran }\end{array}$ & 0,8 & 99,2 \\
\hline 2 & $\begin{array}{l}\text { Pembelajaran menggunakan modul menjadikan } \\
\text { saya lebih aktif }\end{array}$ & 87,5 & 12,5 \\
\hline 3 & Modul dapat digunakan dalam kondisi apapun & 91,4 & 8,6 \\
\hline 4 & Desain modul menarik dengan ilustrasi yang jelas & 90,6 & 9,4 \\
\hline 5 & $\begin{array}{l}\text { Bahasa dalam modul tidak mudah dipahami dan } \\
\text { komunikatif }\end{array}$ & 11,7 & 88,3 \\
\hline 6 & Modul disajikan dengan runtut dan jelas & 87,5 & 12,5 \\
\hline 7 & $\begin{array}{l}\text { Dengan modul saya mampu mengukur tingkat } \\
\text { pemahaman terhadap materi }\end{array}$ & 89,1 & 10,9 \\
\hline 8 & $\begin{array}{l}\text { Modul tidak memudahkan saya dalam memahami } \\
\text { materi }\end{array}$ & 8,6 & 91,4 \\
\hline 9 & $\begin{array}{l}\text { Materi pelajaran yang saya terima menjadi lebih } \\
\text { nyata }\end{array}$ & 90,6 & 9,4 \\
\hline 10 & $\begin{array}{l}\text { Modul membantu saya dalam menemukan konsep } \\
\text { baru }\end{array}$ & 79,7 & 20,3 \\
\hline
\end{tabular}

Berdasarkan Tabel 3 diketahui bahwa sebanyak 99,2\% siswa setuju bahwa modul ethno-edutainment yang digunakan menarik. Sebanyak $87,5 \%$ siswa setuju bahwa pembelajaran menggunakan modul ethno-edutainment membuat mereka semakin aktif. Sebanyak 91,4 \% siswa merasa modul ethno-edutainment dapat digunakan dalam kondisi apapun. (Sungkono, 2009) menjelaskan modul 
memiliki manfaat dalam pengembangannya yaitu siswa dapat belajar tanpa kehadiran guru, dapat belajar kapan saja dan dimana saja, dapat belajar sesuai kemampuannya, serta melalui modul dapat membantu siwa belajar mandiri. Sebanyak $90,6 \%$ siswa setuju bahwa desain dan ilustrasi modul ethno-edutainment menarik. Mudhoffir (Budiono, E., \& Susanto, 2006) bahwa modul yang desain kegiatannya kurang variatif cenderung membuat peserta didik bosan. Oleh karena itu, agar kegiatannya tidak membosankan maka modul perlu dikemas dengan kegiatan yang menyenangkan.

Sebanyak $88,3 \%$ siswa setuju bahwa bahasa yang digunakan mudah dipahami dan komunikatif. (Rosyidah, A.N., Sudarmin, S.S., \& Siadi, 2013) modul yang baik adalah modul yang menggunakan bahasa yang sesuai dengan tingkat perkembangan peserta didik. Sebanyak $87,5 \%$ siswa setuju bahwa modul ethno-edutainment disajikan dengan runtut dan jelas. (Syahroni, M.W., Dewi, N.R., 2016)modul mempunyai susunan yang jelas dan dapat membantu memotivasi.

Sebanyak 89,1\% siswa setuju bahwa modul mampu mengukur tingkat pemahaman siswa terhadap modul ethno-edutainment. Sebanyak 91,4\% siswa merasa bahwa modul ethno-edutainment memudahkan mereka untuk memahami materi. Sebanyak 90,6\% siswa merasa materi yang ada di modul ethno-edutainment membuat materi lebih nyata. (Budiono, E., \& Susanto, 2006) dalam pengembangan modul sebaiknya disertai cotoh agar memudahkan siswa dalam belajar. Sebanyak $79,7 \%$ ssiswa setuju bahwa modul ethno-edutainment membantu dalam menemukan konsep. (Izzatin, N., Hindarto, N., \& Pamelasari, 2013) modul sebaiknya memiliki kedalaman materi agar kemampuan peserta didik meningkat.

Setelah menentukan skor respon masing-masing siswa dilanjutkan dengan menentukan kriteria respon siswa. Pada Tabel 4 berikut ini merupakan hasil rekapitulasi kriteria respon siswa.

Tabel 4. Rekapitulasi kriteria respon siswa

\begin{tabular}{ccc}
\hline $\begin{array}{c}\text { Kriteria Respon } \\
\text { Siswa }\end{array}$ & Jumlah Siswa & Persentase \\
\hline Positif & 28 & $87,5 \%$ \\
Sedang & 4 & $12,5 \%$ \\
Negatif & 0 & $0 \%$ \\
\hline
\end{tabular}


Dari Tabel 4 menunjukkan bahwa sebanyak 28 siswa atau 87,5\% memberikan penilaian terhadap modul dengan kriteria respon yang positif. Pada kriteria respon siswa yang termasuk sedang sebanyak 4 siswa atau sebesar $12,5 \%$. Sedangkan 0 siswa tidak ada yang menunjukkan respon negatif.

Data dianalisis secara kuantitatif dengan menentukan skor respon siswa terhadap modul ethno-edutainment kemudian skor siswa dikelompokkan sesuai kriteria pada tabel. Berdasarkan data pada Tabel 4 menunjukkan bahwa 28 siswa memperoleh respon positif. Dari 28 siswa kemudian ditentukan indikator keberhasilannya. Hasil persentase angket respon siswa menunjukkan bahwa yang mendapatkan respon positif sebanyak $87,5 \%$ yang artinya modul ethno-edutainment berhasil digunakan dengan baik karena telah memperoleh hasil lebih dari atau sama dengan $80 \%$.

\section{Hasil Analisis Respon Guru Terhadap Modul Ethno- Edutainment}

Guru juga memberikan respon terhadap penggunaan modul ethno-edutainment. Respon guru terhadap penggunaan modul ethnoedutainment yang diperoleh dengan wawancara terstruktur dapat dilihat dalam Tabel 5 berikut ini.

Tabel 5. Rekapitulasi hasil wawancara terhadap guru

\begin{tabular}{llll}
\hline No & Pernyataan & Jawaban Guru \\
\hline 1 & Materi modul sesuai dengan KI dan KD? & Ya, sesuai dengan KI dan KD \\
2 & Isi modul sesuai & tingkat & Sesuai, baik materi, bahasa, dan \\
& perkembangan siswa & gambar \\
3 & Modul mudah dipahami siswa & Ya \\
4 & Gambar dan huruf jelas & Ya, dapat dibaca dengan jelas \\
5 & Kegiatan dalam & modul & Ya, terutama kegiatan bernyanyi \\
& mengaktifkan siswa & & \\
6 & Kendala dalam menggunakan modul & Siswa harus sudah suka membaca \\
7 & Kelebihan modul & Siswa lebih aktif, pengenalan budaya \\
8 & Modul membantu meningkatkan & Ya, pendidikan karakter cinta tanah air \\
& karakter cinta tanah air & disisipkan dalam materi dengan baik \\
9 & Modul layak digunakan sebagai bahan ajar & Layak \\
10 & Keberlanjutan penggunaan modul & Tertarik menggunakan dalam \\
& & pembelajaran selanjutnya \\
\hline
\end{tabular}


Guru memberikan tanggapan yang baik dengan penggunaan modul ethno-edutainment. Guru menyatakan bahwa modul ethno-edutainment memiliki kelebihan karena berkonten budaya sehingga membuat pembelajaran lebih aktif. Hal ini sejalan dengan (Wanabuliandari, S., \& Purwaningrum, 2018) bahwa pembelajaran akan menarik dan aktif jika konten materi dekat dengan siswa. (Wihyanti, R., Subiyantoro, S., \& Fadhilah, 2018) menyatakan bahwa kondisi budaya lokal setempat yang beragam dapat memberikan tantangan sekaligus peluang bagi sekolah untuk menanamkan nasionalisme dan watak islamiyah pada siswa. Penginternalisasian nilai-nilai budaya dan keragaman dalam pembelajaran dapat melahirkan nilai-nilai sosio kultural yang baik bagi siswa (Rohman, M., \& Mukhibat, 2017). Guru juga setuju bahwa materi disajikan dengan baik terutama dalam menyisipkan karakter cinta tanah air. (Wanabuliandari, S., Ardianti, S., Saptono, S., Alimah, S., \& Kurniasih., 2018) menyatakan bahwa penggunaan modul ethnoedutainment dapat mengembangkan karakter cinta tanah air pada bangsa Indonesia mengingat Indonesia sebagai negara multicultural. Senada dengan (Yunus, 2013) pembangunan karakter bangsa dapat dilakukan dengan pembelajaran berbasis budaya lokal. Menurut Guru modul ethno-edutainment yang dikembangkan layak untuk digunakan. Hal ini dikarenakan penyusunan modul ethno-edutainment sudah disesuaikan dengan atuaran BSNP dan penyusunannya memperhatikan karakteristik siswa. (Daryanto, 2013) menyatakan bahwa modul merupakan salah satu bahan ajar yang dikemas secara utuh, sistematis, terencana dan didesain untuk membantu siswa dalam menguasai tujuan pembelajaran. Guru tertarik untuk menggunakan modul ethno-edutainment pada pembelajaran selanjutnya.

\section{Simpulan}

Seorang guru harus selalu memperhatikan perkembangan IPTEK. Dengan memperhatikan perkembangan IPTEK dapat membantu guru untuk meningkatkan keterampilan dalam mengelola proses pembelajaran. Salah satu cara meningkatkan keterampilan guru dalam mengelola proses pembelajaran adalah dengan memperkaya sumber dan media pembelajaran. Memperkaya sumber dan media pembelajaran dapat dilakukan dengan mengolah informasi di lingkungan siswa dengan menghubungkan materi dengan kebudayaan 
Respon Siswa dan Guru Terhadap Modul Ethno-Edutainment di sekolah Islam Terpadu

di sekitar siswa. Selain itu, budaya lokal dapat membantu guru untuk menanamkan karakter.

Salah satu cara menggunakan sumber dan media pembelajaran yang dapat menanamkan karakter adalah melalui bahan ajar. Bahan ajar yang dapat digunakan oleh siswa dapat berupa modul. Modul dapat membantu siswa untuk belajar secara mandiri sehingga akan memudahkan siswa untuk belajar dimanapun dan kapanpun. Modul yang digunakan oleh siswa dapat dikembangkan sesuai dengan kebutuhan dan karakteristik siswa. Dengan menggunakan modul berkonten ethno atau berkaitan dengan budaya akan membantu siswa dalam memahami materi maupun membantu guru menanamkan karakter terutama karakter cinta tanah air. Selain mengunakan konten ethno, pengembangan modul perlu memasukkan unsur edutainment agar kegiatan pembelajaran lebih menarik dan menyenangkan. Dengan demikian, melalui pengembangan modul ethno-edutainment dapat membantu guru dalam menanamkan karakter dan meningkatkan keterampilan guru dalam pengelolaan pembelajaran serta dapat membantu siswa dalam memahami materi sehingga pembelajaran lebih bermakna.

Dalam pengembangan modul ethno-edutainment perlu diuji kepraktisannya untuk mengetahui seberapa baik dan menarik modul untuk digunakan sebagai bahan ajar menurut siswa dan guru. Kepraktisan modul ethno-edutainment dapat diperoleh melalui respon siswa dan guru terhadap modul ethno-edutainment. Modul ethno-edutainment dikatakan praktis jika memenuhi kriteria yaitu (1) banyaknya siswa yang memberikan respon positiflebih dari atau sama dengan $80 \%$, dan (2) respon guru terhadap modul ethno-edutainment minimal baik. Modul ethno-edutainment yang dinyatakan praktis dapat digunakan pada siswa sekolah dasar berbasis islam di Kudus.

Aspek kemenarikan modul saat pembelajaran mendapatkan jumlah skor 472 atau aspek kemenarikan dipilih sebanya 92,2\% siswa setuju bahwa modul ethno-edutainment menarik. Aspek bahasa mendapatkan jumlah skor 225 yang berarti 87,9\% siswa setuju bahwa modul ethno-edutainment menggunakan bahasa yang baik, mudah dimengerti dan sistematis. Sedangkan pada aspek materi mendapatkan jumlah skor 447 yang artinya 87,3\% siswa setuju bahwa materi yang di uraikan membuat siswa lebih aktif dan lebih mudah memahami materi. 
Dari data hasil rekapitulasi tiap pernyataan dari angket respon siswa diketahui bahwa sebanyak 99,2\% siswa setuju bahwa modul ethno-edutainment yang digunakan menarik. Sebanyak $87,5 \%$ siswa setuju bahwa pembelajaran menggunakan modul ethno-edutainment membuat mereka semakin aktif. Sebanyak 91,4\% siswa merasa modul ethno-edutainment dapat digunakan dalam kondisi apapun . Sebanyak 90,6\% siswa setuju bahwa desain dan ilustrasi modul ethnoedutainment menarik. Sebanyak $88,3 \%$ siswa setuju bahwa bahasa yang digunakan mudah dipahami dan komunikatif. Sebanyak $87,5 \%$ siswa setuju bahwa disajikan dengan runtut dan jelas. Sebanyak $89,1 \%$ siswa setuju bahwa modul mampu mengukur tingkat pemahaman siswa terhadap modul ethno-edutainment. Sebanyak $91,4 \%$ siswa merasa bahwa modul ethno-edutainment memudahkan mereka untuk memahami materi. Sebanyak 90,6\% siswa merasa materi yang ada di modul ethno-edutainment membuat materi lebih nyata. Sebanyak $79,7 \%$ siswa setuju bahwa modul ethno-edutainment membantu dalam menemukan konsep.

Pada kriteria respon siswa yang positif sebanyak 28 siswa atau sebesar $87,5 \%$. Pada kriteria respon siswa yang termasuk sedang sebanyak 4 siswa atau sebesar $12,5 \%$. Sedangkan 0 siswa tidak ada yang menunjukkan respon negatif. Dari 28 siswa kemudian ditentukan indikator keberhasilannya. Hasil persentase angket respon siswa menunjukkan bahwa yang mendapatkan respon positif sebanyak $87,5 \%$ yang artinya modul ethno-edutainment berhasil digunakan dengan baik.

Guru memberikan tanggapan yang baik dengan penggunaan modul ethno-edutainment. Guru menyatakan bahwa modul ethnoedutainment memiliki kelebihan karena berkonten budaya sehingga membuat pembelajaran lebih aktif. Guru juga setuju bahwa materi disajikan dengan baik terutama dalam menyisipkan karakter cinta tanah air. Menurut Guru modul ethno-edutainment yang dikembangkan layak untuk digunakan. Hal ini dikarenakan penyusunan modul ethno-edutainment sudah disesuaikan dengan atuaran BSNP dan penyusunannya memperhatikan karakteristik siswa. Guru tertarik untuk menggunakan modul ethno-edutainment pada pembelajaran selanjutnya. Oleh karena itu dapat disimpulkan bahwa tanggapan guru terhadap modul ethno-edutainment pada kategori baik. 
Dalam pengembangan modul ethno-edutainment juga ditemui beberapa kendala. Salah satu kendala yang dialami oleh peneliti yaitu dalam menentukan kebudayaan lokal yang dikaitkan dengan materi pembelajaran di sekolah dasar. Perlu ketelitian dalam mencermati materi pokok yang akan disampaikan dalam pembelajaran agar dapat dikaitkan dengan keunggulan lokal daerah. Selain itu, kendala lainnya yang dialami siswa yaitu modul ethno-edutainment terlalu banyak karena mencakup pembelajaran tematik, sehingga membuat siswa sedikit bosan ketika harus membaca modul tersebut dalam sekali waktu.

Dalam pengembangan modul ethno-edutainment ini guru perlu membekali diri dengan berbagai informasi terkait dengan budaya local disekitar siswa. Hal ini dilakukan karena dalam mengembangankan modul ethno-edutainment guru harus mampu mengaitkan materi yang diajarkan dengan konten budaya local setempat. Agar pembelajaran tidak membosankan, guru dapat meminta siswa untuk membaca modul ethno-edutainment di rumah terlebih dahulu sehingga guru dapat memfasilitasi kesulitan dari siswa. Dengan demikian pembelajaran tidak akan membosankan. Untuk langkah pengembangan selanjutnya adalah dengan mengembangkan modul ethno-edutainment dalam bentuk aplikasi agar dapat dipelajari dimana saja dan mudah dibawa kemana saja.

\section{Ucapan Terima Kasih}

Penelitian ini dapat berjalan dengan lancar karena memperoleh dukungan dari beberapa pihak. Kami mengucapkan terima kasih kepada beberapa pihak yang telah mendukung selama kegiatan penelitian berlangsung. Pertama kami mengucapkan terima kasih kepada DRPM Ristek Dikti yang telah memberikan dana untuk Penelitian Kerjasama Antar Perguruan Tinggi (PKPT). Kedua, kami mengucapkan terima kasih kepada Rektor Universitas Muria Kudus dan Rektor Universitas Negeri Semarang yang telah memberikan fasilitas dalam kegiatan penelitian. Selanjutnya, kami juga mengucapkan terima kasih kepada Kepala SD IT Umar Bin Khattab Kudus yang telah memberikan izin dan memfasilitasi dalam kegiatan penelitian. 


\section{DAFTAR PUSTAKA}

Agustina, S., Suntoro, I., \& Nurmalisa, Y. (2013). Peran Sekolah Islam Terpadu Dalam Pembentukan Karakter Religius Siswa (Study kasus di SDIT Islam Terpadu Permata Bunda Gedung Meneng Rajabasa Bandar Lmpung) TP 2012/2013. Jurnal Kultur Demok, 1(3). Retrieved from http://jurnal.fkip.unila. ac.id/index.php/JKD/article/view/771/484

Agustinova, D. E. (2014). Hambatan Pendidikan Karakter Di Sekolah Islam Terpadu (Studi Kasus SD IT Al Hasna Klaten). ISTORIA, 10(1), 1-11. Retrieved from https://journal.uny. ac.id/index.php/istoria/article/view/3598/3076

Alfiriani,A., Hutabri, E. (2017). Practicality And Effectiviness of Bilingual Computer-Based Learning Module. Jurnal Kependidikan, 1(1), 12-23. Retrieved from https://journal. uny.ac.id/index.php/jk/article/view/10896/pdf

Ardianti, S.D, \& Ristiyani, R. (2017). Pemahaman Pendidikan Seks Usia Dini Melalui Modul Anggota Tubuh Manusia. Jurnal Pendidikan Sains, 5(2), 65-70. Retrieved from https://jurnal.unimus.ac.id/index.php/JPKIMIA/article/ view $/ 2989 / 2908$

Ardianti, S.D., Pratiwi, I.A., \& Kanzunnudin, M. (2017). Implementasi Project Based Learning (PjBL) Berpendekatan Science Edutainment Terhadap Kreativitas Peserta Didik. Jurnal Refleksi Edukatika. Jurnal Refleksi Edukatika, 7(2), 145-150. Retrieved from http://jurnal.umk.ac.id/index. $\mathrm{php} / \mathrm{RE} /$ article/view/1225

Ardianti, S.D., Wanabuliandari, S., \& Rahardjo, S. (2017). Peningkatan Perilaku Peduli Lingkungan dan Tanggung Jawab Melalui Model E-JAS dengan Pendekatan Science Edutainment. Jurnal Ilmiah Pendidikan Dasar, 4(1), 1-7. Retrieved from http://jurnal.unissula.ac.id/index.php/pendas/article/ view/995

Ardianti, S. D. (2015). Pengaruh Modul Tematik Inquiry-Discovery Terhadap Hasil Belajar Siswa Materi Metabolisme Pembentuk 
Bioenergi. Refleksi Edukatika: Jurnal Ilmiah Kependidikan, 5(2), 1-6. Retrieved from http://jurnal.umk.ac.id/index. $\mathrm{php} / \mathrm{RE} /$ article/view/584/607

Brata, I. B. (2016). Kearifan Budaya Lokal Perekat Identitas Budaya Bangsa. Jurnal Bakti Saraswati, 5(1), 9-16. Retrieved from https://ojs.unmas.ac.id/index.php/Bakti/article/view/226

Budiono, E., \& Susanto, H. (2006). Penyusunan dan Penggunaan Modul Pembelajaran Berdasar Kurikulum Berbasis Kompetensi Sub Pokok Bahasan Analisa uantitatif Untuk Soal-soal Dinamika Sederhana Pada Kelas X Semester 1 SMA. Jurnal Pendidikan Fisika Indonesia, 4(2), 79-87. Retrieved from https://journal.unnes.ac.id/nju/index.php/JPFI/ article/view/166

Daryanto, D. (2013). Menyusun Modul. Yogyakarta: Gava Media.

Efendi, A. (2009). Beberapa Catatan tentang Buku Teks Pelajaran di Sekolah. INSANIA, 14(2), 320-333. Retrieved from ejournal.iainpurwokerto.ac.id/index.php/insania/article/ view/334/299\%0A

Hawi, A. (2015). Sistem Full-Day School di Sekolah Dasar Islam Terpadu (SDIT) Studi Kasus di Izzuddin Palembang. Jurnal Istinbath, 15(2), 71-87. Retrieved from http://jurnal. radenfatah.ac.id/index.php/istinbath/article/view/787

Hobri. (2009). Model-model Pembelajaran Inovatif. Jember: Center of Society Studies Jember.

Izzatin, N., Hindarto, N., \& Pamelasari, S. D. (2013). Pengembangan Modul Tematik dan Inovatif Berkarakter pada Tema Pencemaran Lingkungan untuk Siswa Kelas VII SMP. Jurnal Pendidikan IPA Indonesia, 2(2), 183-188. Retrieved from https://journal.unnes.ac.id/nju/index.php/jpii/article/ view/2721

Pratiwi, I.A., Ardianti, S.D., \& Kanzunnudin, M. (2018). Peningkatan Kemampuan Kerjasama Melalui Model Project Based Learning ( $\mathrm{PjBL}$ ) Berbantuan Metode Edutainment Pada Mata Pelajaran Ilmu Pengetahuan Sosial. Jurnal Refleksi Edukatika, 8(2), 177-182. Retrieved from http://jurnal.umk. ac.id/index.php/RE/article/view/2357/1356 
Rohman, M., \& Mukhibat, M. (2017). Internalisasi Nilai-Nilai Sosio-Kultural Berbasis Etno-Religi Di MAN Yogyakarta III. Edukasia: Jurnal Penelitian Dan Pendidikan Islam, 12(1), 3456. Retrieved from http://journal.stainkudus.ac.id/index. $\mathrm{php} /$ Edukasia/article/view/1771/pdf

Rosyidah, A.N., Sudarmin, S.S., \& Siadi, K. K. (2013). Pengembangan Modul IPA Berbasis Etnosains Zat Aditif dalam Bahan Makanan untuk Kelas VIII SMP Negeri 1 Pegandon Kendal. Unnes Science Education Journal, 2(1), 133-139. Retrieved from https://journal.unnes.ac.id/sju/index.php/usej/ article/view/1765

Sungkono, S. (2009). Pengembangan dan Pemanfaatan Bahan Ajar Modul Dalam Proses Pembelajaran. Majalah Ilmiah Pembelajaran, Mei(1), 1-13. Retrieved from https://journal. uny.ac.id/index.php/mip/article/view/6154/5341

Suyatno. (2013). Sekolah Islam Terpadu; Filsafat, Ideologi, dan Tren Baru Pendidikan Islam di Indonesia. Jurnal Pendidikan Islam. Jurnal Pendidikan Islam, 2(2), 355-377. Retrieved from http://ejournal.uin-suka.ac.id/tarbiyah/JPI/article/ view/1151

Syahroni, M.W., Dewi, N.R., \& K. (2016). The Effect Of Using digimon (Science Digital Module) with Scientific Approach At The Visualization of Students Independence And Learning Result. Jurnal Pendidikan IPA Indonesia, 5(1), 116-122. Retrieved from https://media.neliti.com/media/ publications / 121533-EN-the-effect-of-using-digimonscience-digi.pdf

Wanabuliandari, S., \& Ardianti, S. A. (2018). Pengaruh Modul E-JAS Edutainment terhadap Karakter Peduli Lingkungan dan Tanggung Jawab. Scholaria: Jurnal Pendidikan Dan Kebudayaan, 8(1), 70-79. Retrieved from http://ejournal. uksw.edu/scholaria/article/view/1248/795

Wanabuliandari, S., \& Purwaningrum, J. P. (2018). Pembelajaran Matematika Berbasis Kearifan lokal Gusjigang Kudus Pada Siswa Slow learner. Eduma: Mathematics Education Learning And Teaching, 7(1), 63-70. Retrieved from http:// 
syekhnurjati.ac.id/jurnal/index.php/eduma/article/ view $/ 2724$

Wanabuliandari, S., Ardianti, S., D., \& Rahardjo, S. (2016). Implementasi Model EJAS Berbasis Mathematic Edutainment Untuk Meningkatkan Prestasi Belajar dan Perilaku Kepedulian Terhadap Lingkungan. Eduma: Mathematics Education Learning And Teaching, 5(2), 34-41. Retrieved from http://syekhnurjati.ac.id/jurnal/index.php/eduma/ article/view/1174/1014

Wanabuliandari, S., Ardianti, S., Saptono, S., Alimah, S., \& Kurniasih., N. (2018). Edutainment Module based on Local Culture of Eastern Pantai Utara, Central Java Reviewed From Experts. International Journal of Engineering \& Technology, 7(2.14), 242-245. Retrieved from https://www.sciencepubco.com/ index.php/ijet/article/view/14684

Wanabuliandari, S. (2016). Pengenalan Budaya Lokal Kota Kudus Melalui Pembelajaran Etnomatematika Pada Anak Usia Dini. In Prosiding Seminar Nasional Bimbingan dan Konseling (pp. 1-12). Retrieved from http://eprints.umk.ac.id/7333/3/ ISI\%281\%29.pdf

Wihyanti, R., Subiyantoro, S., \& Fadhilah, S. . (2018). Internalisasi Karakter Nasionalisme Dalam Kediversitasan Ethnis Di Sekolah Dasar Islam. Edukasia: Jurnal Penelitian Pendidikan Islam., 13(1), 79-104. Retrieved from http:// journal.stainkudus.ac.id/index.php/Edukasia/article/ view/2881/pdf

Yunus, R. (2013). Transformasi Nilai-Nilai Budaya Lokal Sebagai Upaya Pembangunan Karakter Bangsa. Jurnal Penelitian Pendidikan. Jurnal Penelitian Pendidikan, 13(1), 67-79. Retrieved from http://ejournal.upi.edu/index.php/JER/ article/view/3508 
